\title{
"Return and volatility spillover between India, UK, USA and European stock markets: The Brexit impact"
}

\begin{tabular}{|c|c|c|}
\hline AUTHORS & Sangeetha G Nagarakatte (iD) & Natchimuthu Natchimuthu (iD) \\
\hline ARTICLE INFO & \multicolumn{2}{|c|}{$\begin{array}{l}\text { Sangeetha G Nagarakatte and Natchimuthu Natchimuthu (2022). Return and } \\
\text { volatility spillover between India, UK, USA and European stock markets: The } \\
\text { Brexit impact. Investment Management and Financial Innovations, 19(1), 121- } \\
\text { 134. doi:10.21511/imfi.19(1).2022.09 }\end{array}$} \\
\hline DOI & \multicolumn{2}{|c|}{ http://dx.doi.org/10.21511/imfi.19(1).2022.09 } \\
\hline RELEASED ON & \multicolumn{2}{|l|}{ Tuesday, 08 February 2022} \\
\hline RECEIVED ON & \multicolumn{2}{|l|}{ Monday, 15 November 2021} \\
\hline ACCEPTED ON & \multicolumn{2}{|l|}{ Tuesday, 01 February 2022} \\
\hline & \multicolumn{2}{|l|}{$((c))$ EY } \\
\hline LICENSE & \multicolumn{2}{|c|}{$\begin{array}{l}\text { This work is licensed under a Creative Commons Attribution } 4.0 \text { International } \\
\text { License }\end{array}$} \\
\hline JOURNAL & \multicolumn{2}{|c|}{ "Investment Management and Financial Innovations" } \\
\hline ISSN PRINT & \multicolumn{2}{|l|}{$1810-4967$} \\
\hline ISSN ONLINE & \multicolumn{2}{|l|}{$1812-9358$} \\
\hline PUBLISHER & \multicolumn{2}{|c|}{ LLC "Consulting Publishing Company "Business Perspectives" } \\
\hline FOUNDER & \multicolumn{2}{|c|}{ LLC "Consulting Publishing Company "Business Perspectives" } \\
\hline & & $\begin{array}{l}\text { E-: } \\
\text { =-:- }\end{array}$ \\
\hline NUMBER OF REFERENCES & NUMBER OF FIGURES & NUMBER OF TABLES \\
\hline 52 & 2 & 5 \\
\hline
\end{tabular}

(C) The author(s) 2022. This publication is an open access article. 


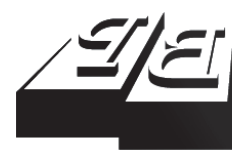

BUSINESS PERSPECTIVES

(O)

LLC "CPC "Business Perspectives"

Hryhorii Skovoroda lane, 10,

Sumy, 40022, Ukraine

www.businessperspectives.org
Received on: $15^{\text {th }}$ of November, 2021 Accepted on: $1^{\text {st }}$ of February, 2022 Published on: $8^{\text {th }}$ of February, 2022

(c) Sangeetha G Nagarakatte, Natchimuthu Natchimuthu, 2022

Sangeetha G Nagarakatte, MCom, Doctoral Student, School of Commerce, Finance and Accountancy, Department of Commerce, Christ University, India. (Corresponding author)

Natchimuthu Natchimuthu, Ph.D., Doctor and Assistant Professor, School of Commerce, Finance and Accountancy, Department of Commerce, Christ University, India.
This is an Open Access article, distributed under the terms of the Creative Commons Attribution 4.0 International license, which permits unrestricted re-use, distribution, and reproduction in any medium, provided the original work is properly cited.

Conflict of interest statement: Author(s) reported no conflict of interest
Sangeetha G Nagarakatte (India), Natchimuthu Natchimuthu, (India)

RETURN AND VOLATILITY SPILLOVER BETWEEN INDIA, UK, USA AND EUROPEAN STOCK MARKETS: THE BREXIT IMPACT

\begin{abstract}
The 2016 Brexit referendum created potential turmoil in financial markets. The purpose of this study is to examine the impact of the Brexit referendum on the return and volatility spillover between the EU, the UK, and the USA stock markets and the Indian stock market during the pre- and post-Brexit referendum period. The VAR and bivariate GARCH BEKK models were employed. The study results suggest that before the Brexit referendum, Indian stock market returns made no significant return spillover on the other markets. On the contrary, following the referendum, Indian stock returns significantly spilled over to France, Germany, the UK, and the USA stock market returns. The study results also identified a substantial increase in the bidirectional volatility spillover between India-France, India-UK, and India-USA during the post-Brexit referendum period. Therefore, the investors' opportunity to invest simultaneously in India, UK, EU, and US stock markets for portfolio diversification is limited. India was affected mainly by its own past shocks before the Brexit referendum. However, after the Brexit referendum, Indian markets are getting more and more integrated with other markets. In order to reap the diversification benefits, a prudent investment strategy will need to be developed in the future, especially during times of economic and political uncertainty and market crisis.
\end{abstract}

\section{Keywords Brexit referendum, volatility transmission, GARCH BEKK, portfolio, diversification}

JEL Classification C58, G11, G15

\section{INTRODUCTION}

In 2016, UK's summer was marked by significant political and economic turbulence. On June 23, 2016, the United Kingdom's European Union membership referendum, also known as the Brexit referendum, was held. On this day, the United Kingdom voted 51.9 percent in favor of leaving the European Union, while 48.1 percent voted against it (Alvarez-Diez et al., 2019). Leave campaign had won the majority of votes. The United Kingdom's decision to exit (Brexit) the European Union has raised many questions of what would be the future trading relationship of the UK with that of the EU and the rest of the world and how this will impact the availability of migrant labor, their future access to the Single Market, and product regulations (Driffield \& Karoglou, 2019). Brexit has been a major source of uncertainty for around $40 \%$ of the UK's business. In the next two trading days following the referendum, global stock markets tumbled. For instance, the leading European stock indices for blue-chip companies like the French CAC 40 and the German DAX decreased by $10 \%$. The UK and US equities did not do well too. FTSE 100 crumbled over $5.8 \%$, and S\&P 500 decreased by $5.5 \%$. Brexit had an adverse impact on the Indian market too. Nifty 50 fell by 181.85 points. The week following the referendum, the pound/euro exchange rate fell by more than 7\% (Guedes et al., 2019). Since then, the future of the UK economy has remained uncertain. 
With the increase in the anxiety of Brexit, more amount of funds was diverted to government bond markets. Immediately following the referendum, investors had shifted their investment to 'risk-free' bond markets. The 10-year US note yields and UK Gilt yields declined by 28 and 35 bps, respectively (Gu \& Hibbert, 2021). Brexit had a negative impact on stock markets, the British pound's value, and the price of crude oil. However, it had a positive impact on the value of gold and government bonds. Investors shifted their investments from riskier assets like stocks, crude oil, and the Great Britain pound to traditionally safer and liquid assets like gold, government bonds, US dollars, and Yen. This behavior is mainly noticed when there is a lot of anxiety or uncertainty. Brexit generates continuous fear in the financial markets (Gu \& Hibbert, 2021). The global EPU (Economic Policy Uncertainty) index reached its highest level, especially after Brexit. Outright rejection of the UK to continue as a member of the European Union has created a new wave in research trying to investigate the potential impact of Brexit on financial markets.

\section{LITERATURE REVIEW}

The past few decades witnessed massive turbulence in financial markets resulting in substantial global crises like Black Monday (1987), Asian financial crisis (1997), Subprime mortgage crises (2008), Eurozone crises (2010), and Chinese stock market crash (2015) (BenSaïda et al., 2018). After these significant global crises, numerous researchers have investigated the concept of volatility spillover across the international stock markets. The volatility spillover concept was first discussed in the pioneering work of Engle et al. (1990). In volatility spillover there are two hypothesis tests: The first one is the "Heatwave Hypothesis," which represents own spillover. According to this hypothesis, a particular market's current volatility results from the same market's previous volatility. The heatwave hypothesis suggests that volatility has a country-specific autocorrelation. This event is known as volatility clustering. The second is the "Meteor shower hypothesis," representing cross-spillovers. According to this hypothesis, a particular market's current volatility results from the same market's previous volatility and other markets' previous volatility. Here, the volatility spillover includes both own spillover and cross spillover. This event is known as volatility transmission. Volatility spillover represents shock transmission that cannot be understood by fundamentals (Bekaert et al., 2014).

Volatility spillover is the result of financial events and market integration (He, 2001). The connection between the markets is the consequences of crises and the effects of various political, economic, and financial events. Stock markets are extremely responsive to the occurrence of domestic and global events. In the past, numerous studies have empirically investigated the spillover of volatility across worldwide stock markets during the crisis period and various financial, political, and economic events (Ahmad et al., 2013; Yousaf \& Hassan, 2019; McIver \& Kang, 2020; Stoupos \& Kiohos, 2021). During the Asian financial crisis, the volatility spillover from Japan and USA to Asian emerging markets became bidirectional and stronger. USA and Japan are the dominant market leader in the Asian region (Li \& Giles, 2015). US Subprime crisis increased the volatility spillover among the stock markets worldwide (Sehgal et al., 2017; Jebran et al., 2017; Lien et al., 2018; Zorgati et al., 2019). In a nutshell, it can be said that major political and economic events have a significant impact on stock price volatility. The stock market serves as the best indicator of the health of the economy. This study mainly focuses on the political event Brexit, which created significant disruption in the financial markets after the global financial crisis of 2008.

The twenty-first century's most remarkable economic and political event is Brexit (Kara et al., 2021). The economic stability of the United Kingdom is at risk due to Brexit, which could have long-term implications. Brexit is likely to generate a significant amount of economic and political uncertainty. The significant political and economic uncertainty increases stock market volatility and affects the financial market by creating financial instability and difficulties (Forbes \& Rigobon, 2002; Diebold \& Yilmaz, 2009; Bloom, 2009; Diebold \& Yilmaz, 2012). Brexit negatively impacted the global equity market (Burdekin et al., 2018). The Brexit referendum adversely affected the travel, leisure, and banking sectors of the British econo- 
my (Ramiah et al., 2017). Brexit instigated policy uncertainty, leading to financial instability in critical markets and damaging the EU and UK's real economy (Belke et al., 2018; Hosoe, 2018; Samitas et al., 2018). Previous studies confirmed that Brexit outcome caused financial contagion as a result of shock and spillover of volatility among European markets would continue to persist (Aristeidis \& Elias, 2018; Li, 2020). Apart from equity markets, currency markets, government bonds, and commodity markets were also affected by the political risk in a Brexit Leave vote (Breinlich et al., 2018). The global economy will be affected by a devalued British pound (Cumming \& Zahra, 2016). The uncertainty of Brexit is seen higher in those industries of the UK that are having trade relations with the European Union and on those industries of the UK dependent on migrant labor of the European Union (Bloom et al., 2018). Brexit is likely to create policy dilemmas for the UK government (Teague \& Donaghey, 2018).

This study analyzes how a political uncertainty like Brexit can change the correlation among these stock markets. As discussed earlier, major stock indices like the French (CAC 40), German (DAX), UK (FTSE 100), and US (S\&P 500) had a significant drop immediately after the Brexit referendum. The reason for choosing these indices is discussed here. The French CAC40 and the German DAX are the leading stock indices for European blue-chip companies. London has substantial economic connections all over the world. India, China, Singapore, Hongkong, and other major Asian economies have a significant economic linkage with London (Lai \& Pan, 2018). The US economy plays a dominant market leader role, and the USA has a significant dynamic information spillover effect on all Asian pacific markets due to significant portfolio investment inflows received by the Asian markets from the USA (Kim, 2005). When analyzing the returns and volatility spillover among Asian, European, and North American stock markets, it is observed that a specific index is affected mainly by those indices that open or close before it (Singh et al., 2010). Hence, Asian indices are affected by lagged returns of European and US indices. Immediately following the Brexit referendum, the global stock markets like the French CAC40, the German DAX, UK FTSE 100, India NIFTY 50, and US S\&P 500 crumbled (Gu \& Hibbert, 2021).
Any slowdown or uncertainty in major economies like the USA, UK, and Europe will first affect its own stock market before it affects the stock market of other countries. The stock markets may be affected by their own spillovers (Heatwave hypothesis) and cross-market spillover (Meteor shower hypothesis). These phenomena can be studied using the BEKK GARCH model. Globalization and financial liberalization are the main reason for increased integration among the financial markets (Vo \& Ellis, 2018). There is a need to understand this interconnection among the markets of different countries, especially for portfolio managers, international investors, and policymakers, to reap the diversification benefits (Zhou et al., 2012). However, changes in market linkages happen constantly. Capturing the correlation that varies with time could have important implications for monetary policies (Tamakoshi \& Hamori, 2014; Boero et al., 2010; Caporale et al., 2017).

During the sub-prime mortgage crisis, Indian stock markets remained unaffected by the volatility spillover of US stock markets among all other countries (Chiang et al., 2013). Indian stock markets were found to be the most efficient market compared to all other markets. Studies suggest that Indian markets are the least risky in terms of market risk (Chiang et al., 2013). India has a negative correlation with that of the Asia Pacific region, which indicates that the impact of the South Asian crisis on India is minimal (Bhar \& Nikolova, 2009). Therefore, this negative correlation suggests diversification opportunities to investors. However, Brexit has created uncertainty among the global business community. India's most important trading partners are the EU and the UK. As a result of Brexit, it will increase the bilateral trade cost between the EU and the UK, which in turn will affect their trade flows. Due to this, their trading partners will be affected indirectly (Roy \& Mathur, 2016). As a result of Brexit, restrictions are imposed on labor movement, which restricts EU citizens to enter and work in the UK. It has led to labor shortage in the UK. Brexit will adversely impact Indian companies that have heavily invested in the UK and having operations in the UK because barriers might make the migration of laborers and professionals to the UK more difficult. Those Indian companies like TATA that have a UK subsidiary that does business in the Eurozone will 
suffer (Chaudhuri, 2020). Companies will consider relocating their plant to other EU countries to enjoy the tariff benefits. United Kingdom used to be India's export market and investment destination within the EU (Tripathi, 2021). Britain was India's gateway to Europe for many Indian firms. Brexit has affected this too. Studies confirm that India and EU would have gained more had UK continued its membership with EU than quitting them (Roy \& Mathur, 2016). Thus, the uncertainty of Brexit has an adverse impact on Indian investments. Therefore, this study will examine whether the uncertainty of Brexit has affected Indian markets and whether it has changed the market linkage of the Indian market with other considered markets.

To the authors' knowledge, the earlier research has not examined the impact of the Brexit referendum on the volatilities of European stock markets like Germany and France, UK, and US stock markets on the Indian stock market using the GARCH BEKK model. Therefore, this study will add to the existing body of knowledge by exploring the impact of Brexit and investigating the linkage between the above-mentioned countries' stock indices on the Indian primary stock index (NIFTY 50) by investigating both return and volatility spillover during the pre- and post-Brexit referendum period. The motivation for this study is that there are many risks associated with Brexit and its impact on the European Union, USA, and UK markets. Understanding its repercussions on the Indian market will help portfolio managers, financial institutions, government, and investors adapt their investment strategies accordingly.

\section{METHOD}

In this study, the daily closing values of the India, France, Germany, the United Kingdom, and the United States indices abbreviated as Nifty 50 (National Stock Exchange Fifty Index), CAC 40 (Cotation Assistée en Continu Index), DAX (Deutscher Aktien Index), FTSE 100 (Financial Times-Stock Exchange 100 Share Index), and S\&P500 (Standard \& Poor's 500 Index), respectively, are used. The historical data of indices were obtained from the Wall Street Journal database. The Brexit referendum was held on June 23, 2016.
The data sample for this paper is split into two categories. The first group includes the period before the Brexit referendum (from January 1, 2012 to June 22, 2016), and the second group comprises the period after the Brexit referendum (from June 23, 2016 to December 31, 2020). The whole study is grouped into pre- and post-Brexit referendum periods. In comparison to monthly or weekly price data, daily stock returns data provides accurate information on stock price fluctuations. While estimating the BEKK GARCH model, the indices mentioned above were grouped into pairs. This way, four pairs were made: India - France, India - Germany, India - United Kingdom, and India the United States of America.

This study used the Vector autoregressive model to investigate the likeliness of return spillover over a period and among different markets. This model evaluates the sign and the strength of the cross-correlation among the returns of different markets (Hung, 2019). The VAR model with one and five lags are estimated during the pre- and post-Brexit referendum period, respectively, to study the linkage among the stock indices returns. The VAR model equations used in this study are as follows:

$$
\begin{aligned}
& r_{\text {india }, t}=a+\sum_{i=1}^{n} b_{1} r_{\text {India }, t-i}+\sum_{i=1}^{n} c_{1} r_{\text {france }, t-i}+ \\
& +\sum_{i=1}^{n} d_{1} r_{\text {gemany }, t-i}+\sum_{i=1}^{n} e_{1} r_{U K, t-i}+ \\
& +\sum_{i=1}^{n} f_{1} r_{U S A, t-i}+\varepsilon_{t}, \\
& r_{\text {france }, t}=a+\sum_{i=1}^{n} b_{1} r_{\text {India }, t-i}+\sum_{i=1}^{n} c_{1} r_{\text {france }, t-i}+ \\
& +\sum_{i=1}^{n} d_{1} r_{\text {gemany }, t-i}+\sum_{i=1}^{n} e_{1} r_{\text {UK, }, t-i}+ \\
& +\sum_{i=1}^{n} f_{1} r_{\text {USA }, t-i}+\varepsilon_{t},
\end{aligned}
$$

$$
\begin{aligned}
& r_{\text {germany }, t}=a+\sum_{i=1}^{n} b_{1} r_{\text {India }, t-i}+\sum_{i=1}^{n} c_{1} r_{\text {france }, t-i}+ \\
& +\sum_{i=1}^{n} d_{1} r_{\text {gemany }, t-i}+\sum_{i=1}^{n} e_{1} r_{U K, t-i}+ \\
& +\sum_{i=1}^{n} f_{1} r_{U S A, t-i}+\varepsilon_{t}, \\
& r_{U K, t}=a+\sum_{i=1}^{n} b_{1} r_{\text {India }, t-i}+\sum_{i=1}^{n} c_{1} r_{\text {france }, t-i}+ \\
& +\sum_{i=1}^{n} d_{1} r_{\text {gemany }, t-i}+\sum_{i=1}^{n} e_{1} r_{U K, t-i}+ \\
& +\sum_{i=1}^{n} f_{1} r_{U S A, t-i}+\varepsilon_{t},
\end{aligned}
$$


$r_{U S A, t}=a+\sum_{i=1}^{n} b_{1} r_{\text {India }, t-i}+\sum_{i=1}^{n} c_{1} r_{\text {france }, t-i}+$

$+\sum_{i=1}^{n} d_{1} r_{\text {gemany }, t-i}+\sum_{i=1}^{n} e_{1} r_{U K, t-i}+$

$+\sum_{i=1}^{n} f_{1} r_{U S A, t-i}+\varepsilon_{t}$,

where $r_{\text {India, },}, r_{\text {France, }, t}, r_{\text {Germany }, t}, r_{U K, t}$, and $r_{U S A, t}$ are the stock index returns of India, France, Germany, the UK and the USA, respectively.

To investigate the spillover of volatility or interdependence between India-France, India-Germany, India-UK, and India-USA, this paper uses the (Baba Engle Kraft Kroner) BEKK GARCH model introduced by Engle and Kroner (1995). One of the crucial features of this model is that conditional covariances matrices are allowed to be positive definite by the construction itself (Majdoub \& Mansour, 2014). This model lets interaction among the conditional covariance and variances. While estimating, this model provides substantial parameter reduction (Hung, 2019). A bivariate BEKK-GARCH model is being used in this study.

$$
\begin{aligned}
& R_{t}=\alpha \Gamma R_{t-1}+u_{t}, \\
& u_{t} \Omega_{t-1} \sim N\left(0, H_{t}\right),
\end{aligned}
$$

where $R_{t}=\left[R_{1, t}, R_{2, t}\right]$ represents returns for the stock market variables and $\alpha$ refers to constant. $u_{t}$ $=\left[\varepsilon_{1, t}, \varepsilon_{2, t}\right]$ denotes residual vector. $H_{t}$ refers to conditional covariance matrix. $\Omega_{t-1}$ represents the set of market information accessible at time $t-1$.

The covariance matrix for the bivariate GARCH BEKK model can be presented as follows:

$$
H_{i j, t}=\left[\begin{array}{ll}
h_{11} & h_{12} \\
h_{21} & h_{22}
\end{array}\right],
$$

The bivariate GARCH BEKK model can be written as follows:

$$
\begin{aligned}
& H_{t}=C^{\prime} C+A^{\prime} \varepsilon \varepsilon^{\prime} A_{11}+B^{\prime} H_{t-1} B, \\
& {\left[\begin{array}{ll}
h_{11, t} & h_{12, t} \\
h_{21, t} & h_{22, t}
\end{array}\right]=\left[\begin{array}{ll}
c_{11, t} & c_{12, t} \\
c_{21, t} & c_{22, t}
\end{array}\right] \cdot\left[\begin{array}{ll}
c_{11, t} & c_{12, t} \\
c_{21, t} & c_{22, t}
\end{array}\right]+} \\
& {\left[\begin{array}{ll}
\alpha_{11} & \alpha_{12} \\
\alpha_{21} & \alpha_{22}
\end{array}\right],\left[\begin{array}{cc}
\varepsilon_{1, t-1}^{2} & \varepsilon_{1, t-1}, \varepsilon_{2, t-1} \\
\varepsilon_{2, t-1} \varepsilon_{1, t-1} & \varepsilon_{2, t-1}^{2}
\end{array}\right]\left[\begin{array}{ll}
\alpha_{11} & \alpha_{12} \\
\alpha_{21} & \alpha_{22}
\end{array}\right]+} \\
& {\left[\begin{array}{ll}
\beta_{11, t} & \beta_{12, t} \\
\beta_{21, t} & \beta_{22, t}
\end{array}\right] \cdot\left[\begin{array}{ll}
h_{11, t-1} & h_{12, t-1} \\
h_{21, t-1} & h_{22, t-1}
\end{array}\right]\left[\begin{array}{ll}
\beta_{11, t} & \beta_{12, t} \\
\beta_{21, t} & \beta_{22, t}
\end{array}\right],}
\end{aligned}
$$
resents GARCH parameters, $\boldsymbol{\alpha}_{k m}$ represents the effect of ' $k$ ' stock market's volatility on ' $m$ ' stock market. $\beta_{k m}$ represents persistence in spillover of volatility between market ' $k$ ' and ' $m$ '.

Bollerslev and Wooldridge (1992) introduced Quasi Maximum Likelihood estimation. The GARCH BEKK model parameters can be estimated by applying the above likelihood function. The equation can be written as follows:

$$
\begin{aligned}
& L(\theta)=-\operatorname{Tn} / 2+\ln (2 \pi)- \\
& -\frac{1}{2} \sum_{t=1}^{T}\left(\ln \left|H_{t}\right|+\varepsilon^{\prime}\left|\frac{1}{H_{t}}\right| \varepsilon_{t}\right),
\end{aligned}
$$

where $\theta$ refers to vector of parameters to be estimated, $n$ denotes number of markets, and $T$ represents the number of observations. This study mainly focuses on $\alpha$ and $\beta$ parameters to assess the characteristics of volatility spillover between markets.

\section{RESULTS}

The results of the ARCH test, unit root test, and descriptive statistics for before and after the Brexit referendum period, respectively, are presented in Table 1. The sample means are found to be positive. Daily returns have increased in case of India and USA during the post period where as daily returns have decreased in France, Germany and the UK during the post period. Standard deviation measures unconditional variance. The volatility increased during the post Brexit referendum period in all countries as measured by standard deviation. All stock indices' returns are found to be leptokurtic during both the sub-periods. However, all the series became highly leptokurtic during the post Brexitreferendum period. The null hypothesis that return series is normally distributed is rejected by the Jarque-Bera test statistics. As per ADF and PP tests, all stock return series are stationary at the 1 per cent level for both sub-periods. The null hypothesis of ARCH test is that "There is no ARCH effect in the residuals". The ARCH test is statistically significant at the $1 \%$ level for all countries except Germany during the post 
Table 1. Descriptive statistics of index returns

\begin{tabular}{|c|c|c|c|c|c|}
\hline Descriptive Statistics & India & France & Germany & UK & USA \\
\hline \multicolumn{6}{|c|}{ Pre-Brexit referendum period } \\
\hline Mean & 0.049103 & 0.027043 & 0.045778 & 0.011354 & 0.045085 \\
\hline Median & 0.062737 & 0.060068 & 0.109823 & 0.043830 & 0.048621 \\
\hline Maximum & 3.948298 & 4.752868 & 5.292440 & 3.661275 & 3.829129 \\
\hline Minimum & -3.952643 & -5.493230 & -4.816500 & -4.779456 & -4.021142 \\
\hline Std. Deviation & 1.039580 & 1.255725 & 1.245974 & 0.937524 & 0.848692 \\
\hline Skewness & -0.161712 & -0.068820 & -0.129165 & -0.168718 & -0.163397 \\
\hline Kurtosis & 3.847366 & 4.370302 & 4.170735 & 4.825365 & 4.704225 \\
\hline Jarque-Bera & $37.29265^{* *}$ & $85.98252 * *$ & $64.56116^{* *}$ & $153.7697^{* *}$ & $132.8682^{* *}$ \\
\hline PP test & $-34.25442 * *$ & $-34.78549 * *$ & $-33.24937^{* *}$ & $-33.99883 * *$ & $-32.65372 * *$ \\
\hline ADF test & $-34.27813^{* *}$ & $-34.52567^{* *}$ & $-33.21837^{* *}$ & $-33.63357^{* *}$ & $-32.36916^{* *}$ \\
\hline ARCH test & $35.86189 * *$ & $17.03677 * *$ & $14.63879 * *$ & $40.30179 * *$ & $45.79528 * *$ \\
\hline Observations & 1088 & 1088 & 1078 & 1071 & 1059 \\
\hline \multicolumn{6}{|c|}{ Post-Brexit referendum period } \\
\hline Mean & 0.054222 & 0.019691 & 0.026679 & 0.001598 & 0.049363 \\
\hline Median & 0.103768 & 0.043787 & 0.066518 & 0.049690 & 0.081935 \\
\hline Maximum & 8.400291 & 8.056079 & 10.41429 & 8.666807 & 8.968316 \\
\hline Minimum & -13.90375 & -13.09835 & -13.05486 & -11.51243 & -12.76521 \\
\hline Std. Deviation & 1.208192 & 1.266733 & 1.301815 & 1.117942 & 1.235270 \\
\hline Skewness & -1.759126 & -1.370725 & -0.871199 & -1.179954 & -1.339523 \\
\hline Kurtosis & 28.07427 & 21.44166 & 20.67636 & 20.83422 & 26.70607 \\
\hline Jarque- Bera & $29517.19 * *$ & $16004.55^{* *}$ & $14328.49 * *$ & $14725.10 * *$ & $25564.54 * *$ \\
\hline PP test & $-36.79915^{* *}$ & $-32.52813^{* *}$ & $-32.94952 * *$ & $-33.40182^{* *}$ & $-39.47633^{* *}$ \\
\hline ADF test & $-13.31256^{* *}$ & $-21.19173^{* *}$ & $-20.92702 * *$ & $-21.86502^{* *}$ & $-8.305606^{* *}$ \\
\hline ARCH test & $37.78200 * *$ & $15.05054^{* *}$ & 1.505654 & $27.42791^{* *}$ & $123.9839 * *$ \\
\hline Observations & 1105 & 1105 & 1090 & 1092 & 1078 \\
\hline
\end{tabular}

Note: $* *$ denotes $p$-values $<1 \%$ significance level, $*$ denotes $p$-values $<5 \%$ significance level.

period. Therefore, the null hypothesis, which The raw series of all five countries' stock markets states that there is no ARCH effect, is rejected. are plotted in Figure 1 and Figure 2. It can be seen The ARCH test confirms the presence of the that there has been fluctuation in all five countries ARCH effect. It implies that the GARCH BEKK before and after the Brexit referendum period. model can be used to estimate the spillover of However, the post-Brexit referendum period saw a volatility between stock indices. substantial increase in fluctuations.

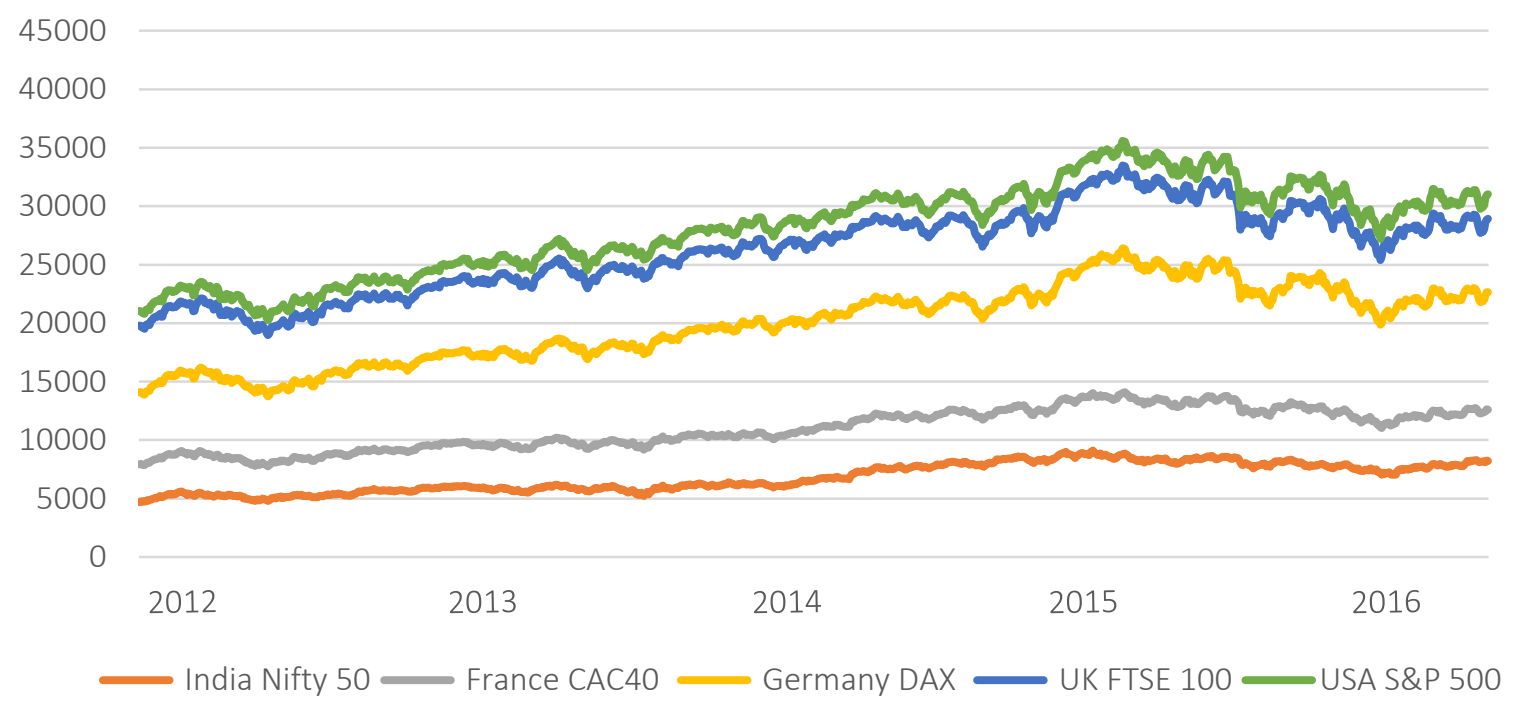

Figure 1. Daily index series for the pre-Brexit referendum period 


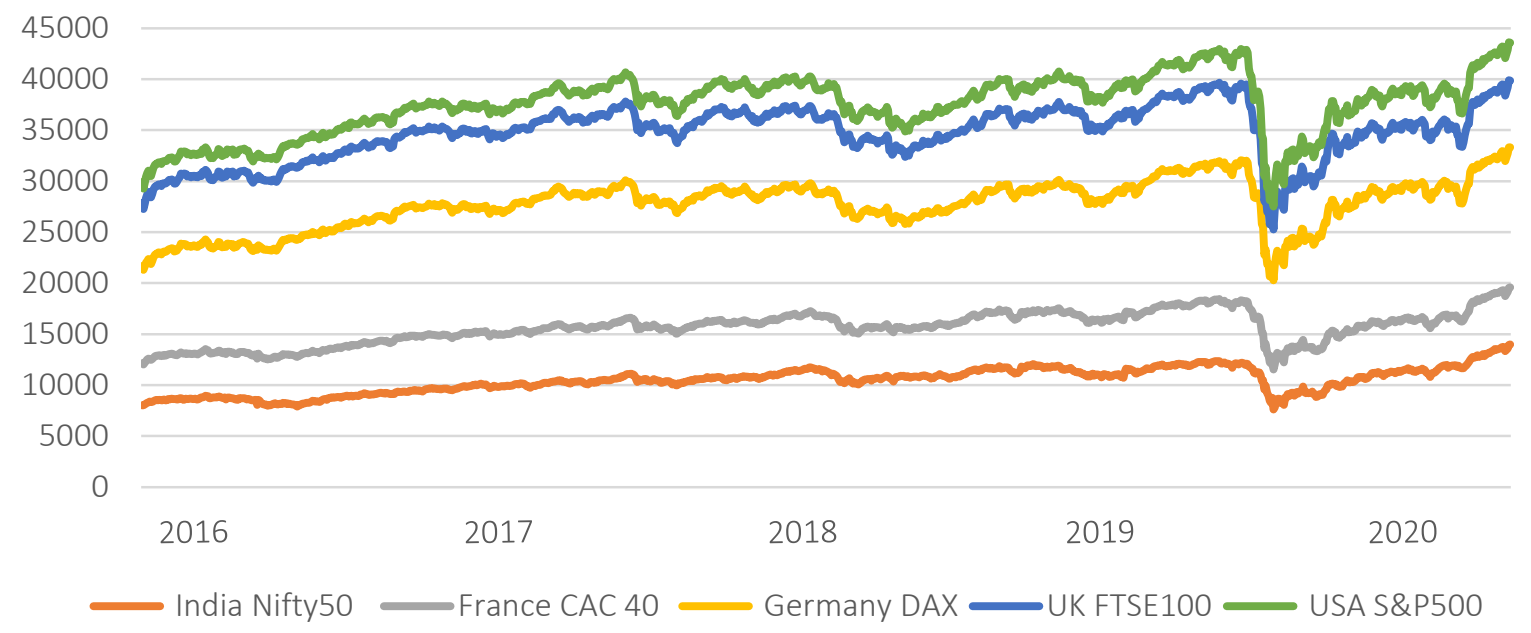

Figure 2. Daily index series for the post-Brexit referendum period

Table 2 presents the sample correlation results for all five stock markets before and after the Brexit referendum periods, respectively. The lowest correlation $(0.037896)$ is between India and USA during the pre-Brexit referendum period. The highest correlation $(0.937171)$ is between Germany and France during the post-Brexit referendum period. In comparison to the period prior to the Brexit referendum, there has been a significant increase in the correlation coeffi- cients between selected countries' stock markets after the Brexit referendum.

The Vector Auto Regression model is used to analyze the return spillover among the selected indices. The lag lengths for pre- and post-Brexit periods are 1 and 5, respectively. The optimum lag lengths were selected based on the suggestions by AIC (Akaike Information Criterion). Table 3 and 4 show the estimated parameters for the VAR mod-

Table 2. Correlation matrix between index returns

\begin{tabular}{|c|c|c|c|c|c|}
\hline Countries & India & France & Germany & UK & USA \\
\hline \multicolumn{6}{|c|}{ Pre-Brexit referendum period } \\
\hline India & 1 & & & & \\
\hline France & 0.121987 & 1 & & & \\
\hline Germany & 0.131873 & 0.930523 & 1 & & \\
\hline UK & 0.157830 & 0.860864 & 0.830667 & 1 & \\
\hline USA & 0.037896 & 0.599648 & 0.575875 & 0.606753 & 1 \\
\hline \multicolumn{6}{|c|}{ Post-Brexit referendum period } \\
\hline India & 1 & & & & \\
\hline France & 0.442541 & 1 & & & \\
\hline Germany & 0.411770 & 0.937171 & 1 & & \\
\hline UK & 0.433082 & 0.880179 & 0.844237 & 1 & \\
\hline USA & 0.330753 & 0.660007 & 0.652553 & 0.627274 & 1 \\
\hline
\end{tabular}

Table 3. Pre-Brexit referendum period, VAR model

\begin{tabular}{|c|c|c|c|c|c|}
\hline \multicolumn{6}{|c|}{ Vector Autoregression Estimates } \\
\hline & INDIA_RET & FRANCE_RET & GERMANY_RET & UK_RET & USA_RET \\
\hline INDIA_RET (-1) & $-0.090820 * *$ & 0.017168 & 0.028621 & 0.029581 & -0.001025 \\
\hline FRANCE_RET (-1) & 0.049768 & -0.021151 & 0.008430 & 0.004980 & -0.007357 \\
\hline GERMANY_RET $(-1)$ & 0.084160 & -0.103877 & -0.049751 & -0.099257 & 0.022393 \\
\hline UK_RET $(-1)$ & 0.091441 & -0.158377 & $-0.213790^{*}$ & $-0.154170^{*}$ & -0.026730 \\
\hline USA_RET (-1) & $0.398476 * *$ & $0.441796^{* *}$ & $0.432154 * *$ & $0.422946 * *$ & -0.012913 \\
\hline
\end{tabular}

Note: $* *$ denotes $p$-values $<1 \%$ significance level, $*$ denotes $p$-values $<5 \%$ significance level. 
el for the pre- and post-Brexit referendum periods, respectively. In general, it is noticed that during both pre- and post-Brexit referendum periods, the US market made a significant return spillover on the stock markets of other four nations. Before the Brexit referendum, the UK's first lag return substantially impacted itself and the Germany stock market. However, after the Brexit referendum, the UK's second lag return made a significant return spillover on German, France's stock market and itself. Also, the UK's third lag returns made significant return spillover to the German stock market.

Prior to the Brexit referendum, India's first lag had a significant return spillover on itself and not on any other stock market returns. On the contrary, during the post-Brexit referendum period, India's first lag return had significant return spillover on itself and France, Germany, UK, and US stock market returns. India's fifth lag returns had return spillover on itself, and India's second lag had significant return transmission on USA stock market returns during the post period. It was also observed that the German stock market returns made no significant impact on the other markets during the pre-Brexit period. On the contrary, German stock returns significantly spilled over to India and USA stock market returns during the post-Brexit referendum period. Germany's second lag returns impacted India and the USA stock market, and Germany's fifth lag significantly impacted USA stock market returns. However, France's stock market returns made no significant return spillover on the other markets during both pre- and post-Brexit referendum periods.

Volatility spillover between Indian stock index and rest of the above considered nations stock indices is examined. To investigate the spillover of volatility, the GARCH-BEKK model is used. The estimated outcome of the BEKK model is shown in Table 5. Here $\mathrm{A}(\mathrm{k}, \mathrm{k})$ represents the ARCH parameter and $\mathrm{B}(\mathrm{k}, \mathrm{k})$ represents $\mathrm{GARCH}$ parameters concerning market $\mathrm{k}$. The essential charac-

Table 4. Post-Brexit referendum period, VAR model

\begin{tabular}{|c|c|c|c|c|c|}
\hline \multicolumn{6}{|c|}{ Vector Autoregression Estimates } \\
\hline & INDIA_RET & FRANCE_RET & GERMANY_RET & UK_RET & USA_RET \\
\hline INDIA_RET (-1) & $-0.359948^{* *}$ & $-0.310017^{* *}$ & $-0.304373^{* *}$ & $-0.292016^{* *}$ & $-0.226555^{* *}$ \\
\hline INDIA_RET (-2) & -0.046460 & -0.030224 & -0.006640 & -0.011808 & $0.093611^{*}$ \\
\hline INDIA_RET (-3) & 0.002347 & -0.024865 & -0.008145 & 0.006332 & 0.057258 \\
\hline INDIA_RET (-4) & 0.020446 & 0.012831 & -0.017770 & 0.078708 & 0.017336 \\
\hline INDIA_RET (-5) & $0.149103 * *$ & -0.022108 & -0.034767 & -0.018102 & -0.062634 \\
\hline FRANCE_RET (-1) & -0.015400 & 0.097686 & 0.094872 & 0.063501 & 0.022423 \\
\hline FRANCE_RET (-2) & -0.193972 & 0.138835 & 0.215549 & 0.154307 & -0.061901 \\
\hline FRANCE_RET (-3) & 0.067940 & 0.013244 & -0.005705 & 0.058578 & 0.042006 \\
\hline FRANCE_RET (-4) & 0.036917 & -0.026661 & -0.122085 & -0.053460 & -0.100882 \\
\hline FRANCE_RET (-5) & 0.026252 & -0.139555 & -0.214069 & -0.116091 & -0.156202 \\
\hline GERMANY_RET $(-1)$ & 0.098246 & -0.038875 & -0.014647 & -0.029679 & 0.144894 \\
\hline GERMANY_RET (-2) & $0.232676^{*}$ & 0.102718 & 0.078679 & 0.088031 & $0.272127 * *$ \\
\hline GERMANY_RET $(-3)$ & 0.117204 & 0.002127 & -0.031025 & -0.046202 & 0.036485 \\
\hline GERMANY_RET (-4) & 0.013574 & -0.002202 & 0.055477 & 0.005152 & 0.167581 \\
\hline GERMANY_RET (-5) & 0.052037 & 0.121970 & 0.147827 & 0.111262 & $0.235699 * *$ \\
\hline UK_RET $(-1)$ & 0.014785 & -0.014385 & -0.086935 & -0.030332 & -0.090558 \\
\hline UK_RET (-2) & 0.127077 & $-0.184655^{*}$ & $-0.207939^{*}$ & $-0.159309^{*}$ & 0.052807 \\
\hline UK_RET $(-3)$ & 0.061913 & 0.124163 & $0.173790 *$ & 0.072994 & 0.067609 \\
\hline UK_RET (-4) & 0.101588 & 0.132572 & 0.166683 & 0.095547 & 0.024183 \\
\hline UK_RET (-5) & -0.114866 & 0.057813 & 0.093201 & 0.032471 & -0.046733 \\
\hline USA_RET $(-1)$ & $0.282904^{* *}$ & $0.166699 * *$ & $0.182901^{* *}$ & $0.186268^{* *}$ & $-0.158849 * *$ \\
\hline USA_RET (-2) & $0.106233^{*}$ & $0.211464 * *$ & $0.176999 * *$ & $0.138875^{* *}$ & 0.055185 \\
\hline USA_RET (-3) & $-0.168118^{* *}$ & $-0.194738^{* *}$ & $-0.180840 * *$ & $-0.190436^{* *}$ & $-0.284801^{* *}$ \\
\hline USA_RET (-4) & $-0.120253^{*}$ & -0.108140 & -0.078191 & -0.072088 & $-0.148995 * *$ \\
\hline USA_RET (-5) & 0.061521 & 0.027433 & 0.060708 & 0.021642 & -0.030607 \\
\hline
\end{tabular}

Note: ${ }^{* *}$ denotes $p$-values $<1 \%$ significance level, $*$ denotes $p$-values $<5 \%$ significance level. 
Table 5. Parameter estimates for the bivariate GARCH BEKK model

\begin{tabular}{|c|c|c|c|c|c|c|c|c|}
\hline \multirow[b]{2}{*}{ Parameter } & \multicolumn{2}{|c|}{ India Nifty50 \& USA S\&P500 } & \multicolumn{2}{|c|}{ India Nifty50 \& UK FTSE100 } & \multicolumn{2}{|c|}{ India Nifty50 \& France CAC 40} & \multicolumn{2}{|c|}{ India Nifty50 \& Germany DAX } \\
\hline & $\begin{array}{l}\text { Pre Brexit } \\
\text { referendum } \\
\text { period }\end{array}$ & $\begin{array}{l}\text { Post Brexit } \\
\text { referendum period }\end{array}$ & $\begin{array}{c}\text { Pre Brexit } \\
\text { referendum period }\end{array}$ & $\begin{array}{c}\text { Post Brexit } \\
\text { referendum period }\end{array}$ & $\begin{array}{c}\text { Pre Brexit } \\
\text { referendum period }\end{array}$ & $\begin{array}{c}\text { Post Brexit } \\
\text { referendum period }\end{array}$ & $\begin{array}{c}\text { Pre Brexit referendum } \\
\text { period }\end{array}$ & $\begin{array}{c}\text { Post Brexit } \\
\text { referendum } \\
\text { period }\end{array}$ \\
\hline \multicolumn{9}{|c|}{ Conditional Mean } \\
\hline mu1. & $0.08048236^{* *}$ & $0.0897043^{* *}$ & $0.058604360^{* *}$ & $0.0881337^{* *}$ & 0.0419405 & $0.0951011^{* *}$ & $0.0553444^{*}$ & $0.0963833^{* *}$ \\
\hline mu2. & $0.08531982^{* *}$ & $0.0882601^{* *}$ & 0.022315209 & 0.0175031 & 0.0213635 & $0.0898070^{* *}$ & $0.0706061^{* *}$ & $0.0716854^{* *}$ \\
\hline \multicolumn{9}{|c|}{ Conditional Variance } \\
\hline A011 & $0.91081590 * *$ & $0.2958076^{* *}$ & $0.928404672^{* *}$ & $0.2656475^{* *}$ & $0.2079160 * *$ & $0.2622542^{* *}$ & $0.2526693^{* *}$ & 0.0963833 \\
\hline A021 & 0.00729514 & $0.0808812^{* *}$ & $0.120135124^{* *}$ & $0.0962370^{* *}$ & 0.0301436 & $0.1122155^{* *}$ & 0.0335084 & $0.0716854^{* *}$ \\
\hline A022 & $0.16933886^{* *}$ & $0.2346354^{* *}$ & $0.185153231^{* *}$ & $0.2017063^{* *}$ & $1.1758660^{* *}$ & $0.2271390^{* *}$ & $0.2469316^{*}$ & 0.0963833 \\
\hline A11 & $0.25462355^{* *}$ & $0.2102694^{* *}$ & $0.309507801^{* *}$ & $0.2576251^{* *}$ & $0.2818612^{* *}$ & $0.2282923^{* *}$ & $0.2565865^{* *}$ & $0.0716854^{* *}$ \\
\hline A21 & 0.03913291 & $0.1585346^{* *}$ & 0.055017516 & $0.0901637^{* *}$ & 0.0655591 & $0.1321359^{* *}$ & 0.0229646 & $0.0963833^{* *}$ \\
\hline A12 & $0.50000000^{* *}$ & $-0.1389748^{* *}$ & $-0.390043578^{* *}$ & -0.0180977 & $-0.2069405^{* *}$ & $0.0862847 *$ & $-0.1140273^{* *}$ & 0.0716854 \\
\hline A22 & $0.23484674^{* *}$ & $0.4915875^{* *}$ & $0.237016398^{* *}$ & $0.4178937^{* *}$ & $0.2843392^{* *}$ & $0.3871304^{* *}$ & $0.2321429 * *$ & 0.0963833 \\
\hline B11 & 0.00000100 & $0.8616929 * *$ & 0.000001000 & $0.8444153^{* *}$ & $0.8597930 * *$ & $0.8504571^{* *}$ & $0.9237603^{* *}$ & 0.0716854 \\
\hline B21 & $0.21042540^{*}$ & $-0.1740152^{* *}$ & $-0.202878250 *$ & $-0.2256607^{* *}$ & 0.2308109 & $-0.2858672^{* *}$ & 0.0178819 & 0.0963833 \\
\hline B12 & -0.07571478 & $0.2380892 * *$ & 0.109180021 & $0.2258051^{* *}$ & 0.1786257 & $0.1871505^{* *}$ & $0.0346525^{* *}$ & 0.0716854 \\
\hline B22 & $0.89745604^{* *}$ & $0.8220165^{* *}$ & $0.944784947^{* *}$ & $0.8955140 * *$ & 0.0000010 & $0.9011962^{* *}$ & $0.9535895^{* *}$ & 0.0963833 \\
\hline
\end{tabular}

Note: ${ }^{* *}$ denotes $p$-values $<1 \%$ significance level, $*$ denotes $p$-values $<5 \%$ significance level. 
teristic of the BEKK model is that causal relation can be systematically explained among variance and covariance. All diagonal elements of $\mathrm{ARCH}$ parameters $A(k, k)$ suggest that the responses of volatility in market $\mathrm{k}$ are dependent on its own lagged shocks. However, all off-diagonal elements of the $\mathrm{ARCH}$ parameters $\mathrm{A}(\mathrm{k}, \mathrm{m})$ capture the past cross innovations. This means that the past cross innovations or shocks are transmitted from stock market $\mathrm{k}$ to stock market $\mathrm{m}$. In other words, when shocks hit market $\mathrm{k}$, the shock is propagated to stock market $\mathrm{m}$. The ARCH parameters $\mathrm{A}(\mathrm{m}, \mathrm{k})$ capture the same effects but from the opposite direction. The results of GARCH BEKK are reported in pairs of the India stock index and the four other countries' stock indices.

Similarly, all off-diagonal elements of the GARCH parameters $\mathrm{B}(\mathrm{k}, \mathrm{m})$ suggest that the ' $\mathrm{m}$ ' stock market's volatility is dependent on ' $k$ ' stock market's volatility (Mohammadi \& Tan, 2015). These results are also presented in pairs of Indian stock indices and the four other countries' stock indices. It is essential to emphasize the conditional variance and conditional covariances when reporting the diagonal elements of the GARCH BEKK model (Vo \& Ellis, 2018). A(1,1) $\mathrm{A}(2,2)$ are the ARCH term of variance equation, which indicates auto regressiveness (ARCH effects). All the diagonal elements $A(1,1) A(2,2)$ except Germany showcased statistically significant ARCH effects for pre- and post-periods. This result indicates conditional variances are dependent on the market's past shocks (Hung, 2020). The result implies that the volatility of India, the USA, the UK, and France equity markets are dependent on their own past innovations.

Under the ARCH parameter $\mathrm{A}(1,2), 1$ always represents India and 2 represents the USA, the UK, France and Germany. The result suggests that $A(1,2)$ parameter estimates are statistically significant for the USA, UK, France, and Germany during the pre-Brexit referendum period. However, it is statistically significant only for the USA and France during the post-Brexit referendum period. When shocks hit the Indian stock market, the shocks were propagated to the USA and France stock markets before and after the Brexit referendum. On the contrary, when shocks hit Indian markets, the shocks were transmitted to the UK and German stock markets only for the pre-Brexit referendum period. This result indicates that past cross innovations or shocks originating from the Indian market influenced the current volatility of the UK, France, Germany, and US stock markets before the Brexit referendum. Even after the Brexit referendum, the past innovations of the Indian markets continued to impact the stock returns of the USA and France significantly. The past innovations of the Indian stock markets had no significant influence on the UK and German stock markets after the Brexit referendum. The past shocks of the USA, the UK, France and Germany had no substantial effect on the Indian markets before the Brexit referendum. On the contrary, the past innovations of the USA, UK, France, and German markets have a substantial influence on the Indian markets after the Brexit referendum.

Additionally, there are three patterns demonstrated by the GARCH effects: First, the diagonal GARCH parameters $\mathrm{B}(1,1)$ and $\mathrm{B}(2,2)$ indicate that each conditional variances are dependent on their past for the given period (Hung, 2020). A significant GARCH effect was noticed in the USA, India and the UK before and after the Brexit referendum. However, a significant GARCH effect was observed in France only after the Brexit referendum, and a significant GARCH effect was observed in Germany before the Brexit referendum. Second, the off-diagonal elements of the GARCH parameters $B(\mathrm{k}, \mathrm{m})$ indicate that the volatility of the stock market ' $m$ ' depends on the volatility of the stock market ' $k$ '. Thirdly, the GARCH parameters $\mathrm{B}(\mathrm{m}, \mathrm{k})$ capture the same effects but in the opposite direction. That is, the ' $k$ ' stock market's volatility depends on the ' $m$ ' stock market's volatility. Similarly, under GARCH parameter B $(1,2)$, 1 represents India and 2 represents the USA, UK, France and Germany.

It is found that there was a unidirectional spillover of volatility from India to Germany before the Brexit referendum. However, there was no spillover of volatility from India to France, UK, and the USA before the Brexit referendum. On the contrary, it is found that there is spillover of volatility from India to France, UK, and the USA after the Brexit referendum. There is significant spillover of volatility from USA and UK to India before the Brexit referendum. However, there is no spillover of volatility from France and Germany to India 
before the Brexit referendum. On the contrary, it is seen that there is spillover of volatility from the UK, the USA, and France to India after the Brexit referendum. However, there is no volatility spillover from Germany to India after the Brexit referendum too. In summary, it is found that there is strong evidence of bidirectional spillover of volatility between India and France, between India and the UK, and between India and the USA after the Brexit referendum.

There are significant ARCH effects in India, the USA, the UK, and France before and after the Brexit referendum. German market had a significant ARCH effect before the Brexit referendum. During the study period, the stock markets of India, the UK, the USA, and France depend on their own history $\mathrm{B}(\mathrm{k}, \mathrm{k})$. In a nutshell, it can be inferred that there was a significant increase in the bidirectional volatility spillover between India and other three countries' stock markets, namely France, USA, and UK, in the post-Brexit referendum period as compared to the pre-Brexit referendum period. It is also observed that there was asymmetry in volatility spillover. That is, the transmission of shocks from one market to another was not uniform. The result suggests an increase in correlation of volatility transmission between India and the other three stock markets, namely the USA, France, and the UK, after the Brexit referendum. This means that India and the other three markets are substantially integrated in the post-Brexit referendum period. This is valuable information for investors who diversify their portfolios in order to minimize risk.

\section{CONCLUSION}

This study aims to investigate the spillover of return and volatility between the stock markets of India and four countries, namely France, Germany, the UK, and the USA, and compare market interactions before and after the Brexit referendum using the VAR model and the bivariate GARCH BEKK model. The results suggested that India did not make a significant return spillover to any other country's stock market during the pre-Brexit period except itself. However, during the post-period, India made substantial return spillover to itself and the other four countries. Before the Brexit referendum period, the past shocks of the USA, the UK, France, and Germany had no considerable influence on the Indian stock market volatility. However, after the Brexit referendum, the past shocks of the USA, the UK, France, and Germany had a considerable influence on the Indian market volatility. Overall, the findings reveal strong evidence of bidirectional spillover of volatility between India and the UK, between India and the USA, and between India and France after the Brexit referendum. Thus, to minimize risk, investors must take caution while investing funds in the Indian stock market along with the EU, UK, and US stock markets. India remained unaffected by the volatility spillover from the US stock market since sub-prime crisis. However, after the Brexit referendum, India was affected by the external shocks of the EU, UK, and US markets, and there was bi-directional volatility spillover between them. Hence, an appropriate asset allocation strategy needs to be developed to enjoy the benefits of diversification in these markets, especially in times of political and economic instability and market crises. Thus, there is a possibility that Indian stock markets will be further exposed to these external shocks in the future.

\section{AUTHOR CONTRIBUTIONS}

Conceptualization: Sangeetha G Nagarakatte, Natchimuthu Natchimuthu.

Data curation: Sangeetha G Nagarakatte.

Formal analysis: Sangeetha G Nagarakatte, Natchimuthu Natchimuthu.

Funding acquisition: Sangeetha G Nagarakatte.

Investigation: Sangeetha G Nagarakatte.

Methodology: Sangeetha G Nagarakatte, Natchimuthu Natchimuthu.

Project administration: Sangeetha G Nagarakatte, Natchimuthu Natchimuthu.

Resources: Sangeetha G Nagarakatte. 
Software: Sangeetha G Nagarakatte, Natchimuthu Natchimuthu. Supervision: Sangeetha G Nagarakatte, Natchimuthu Natchimuthu. Validation: Sangeetha G Nagarakatte, Natchimuthu Natchimuthu. Visualization: Sangeetha G Nagarakatte, Natchimuthu Natchimuthu. Writing - original draft: Sangeetha G Nagarakatte.

Writing - review \& editing: Sangeetha G Nagarakatte, Natchimuthu Natchimuthu.

\section{REFERENCES}

1. Ahmad, W., Sehgal, S., \& Bhanumurthy, N. R. (2013). Eurozone crisis and BRIICKS stock markets: Contagion or market interdependence? Economic Modelling, 33, 209-225. https://doi.org/10.1016/j.econmod.2013.04.009

2. Alvarez-Diez, S., Baixauli-Soler, J. S., \& Belda-Ruiz, M. (2019). Comovements between the British pound, the euro and the Japanese yen: the Brexit impact. Journal of Economic Studies, 46(2), 467-481. https://doi.org/10.1108/JES-012018-0007

3. Aristeidis, S., \& Elias, K. (2018). Empirical analysis of market reactions to the UK's referendum results - How strong will Brexit be? Journal of International Financial Markets, Institutions and Money, 53, 263-286. https://doi. org/10.1016/j.intfin.2017.12.003

4. Bekaert, G., Ehrmann, M., Fratzscher, M., \& Mehl, A. (2014). The Global Crisis and Equity Market Contagion. Journal of Finance, 69(6), 2597-2649. https://doi. org/10.1111/jofi.12203

5. Belke, A., Dubova, I., \& Osowski, T. (2018). Policy uncertainty and international financial markets: the case of Brexit. Applied Economics, 50(34-35), 3752-3770. https://doi.org/10.1080/00036846 2018.1436152

6. BenSaïda, A., Litimi, H., \& Abdallah, O. (2018). Volatility spillover shifts in global financial markets. Economic Modelling, 73(February), 343-353. https:// doi.org/10.1016/j.econmod.2018.04.011

7. Bhar, R., \& Nikolova, B. (2009). Return, volatility spillovers and dynamic correlation in the BRIC equity markets: An analysis using a bivariate EGARCH framework. Global Finance Journal, 19(3), 203-218. https://doi.org/10.1016/j. gf. 2008.09.005

8. Bloom, N. (2009). The Impact of Uncertainty Shocks. Econometrica. https://doi.org/doi.org/10.3982/ ECTA6248

9. Bloom, N., Bunn, P., Chen, S., Mizen, P., Smietanka, P., Thwaites, G., \& Young, G. (2018). Brexit and Uncertainty: Insights from the Decision Maker Panel. Fiscal Studies, 39(4), 555-580. https://doi. org/10.1111/1475-5890.12179

10. Boero, G., Silvapulle, P., \& Tursunalieva, A. (2010). Modelling the bivariate dependence structure of exchange rates before and after the introduction of the Euro: A semi-parametric approach. International Journal of Finance and Economics, 16(4), 357-374. https://doi.org/10.1002/ijfe.434

11. Bollerslev, T., \& Wooldridge, J. (1992). Quasi-maximum likelihood estimation and inference in dynamic models with time-varying covariances. Econometric Reviews, 11(2), 143172 .

12. Breinlich, H., Leromain, E., Novy, D., Sampson, T., \& Usman, A. (2018). The Economic Effects of Brexit: Evidence from the Stock Market. Fiscal Studies, 39(4), 581623. https://doi.org/10.1111/14755890.12175

13. Burdekin, R. C. K., Hughson, E., \& $\mathrm{Gu}$, J. (2018). A first look at Brexit and global equity markets. Applied Economics Letters, 25(2), 136-140. https://doi.org/10.1080/13504851. 2017.1302057

14. Caporale, G. M., Gil-Alana, L., \& Plastun, A. (2017). Searching for Inefficiencies in Exchange Rate Dynamics. Computational Economics, 49(3), 405-432. https:// doi.org/10.1007/s10614-0169567-2

15. Chaudhuri, P. P. (2020). Brexit and India-UK Relations. Palgrave Macmillan, Singapore. https://doi. org/10.1007/978-981-15-3917-6_5

16. Chiang, S.-M., Chen, H.-F., \& Lin, C.-T. (2013). The spillover effects of the sub-prime mortgage crisis and optimum asset allocation in the BRICV stock markets. Global Finance Journal, 24(1), 30-43. https://doi.org/10.1016/j. gf. 2013.03 .001

17. Cumming, D. J., \& Zahra, S. A. (2016). International Business and Entrepreneurship Implications of Brexit. British Journal of Management, 27(4), 687-692. https://doi.org/10.1111/14678551.12192

18. Diebold, F. X., \& Yilmaz, K. (2009). Measuring financial asset return and volatility spillovers, with application to global equity markets. The Economic Journal, 119(534), 158-171. https://doi.org/10.1111/j.14680297.2008.02208.x

19. Diebold, F. X., \& Yilmaz, K. (2012). Better to give than to receive: Predictive directional measurement of volatility spillovers. International Journal of Forecasting, 28(1), 57-66. https://doi.org/10.1016/j.ijforecast.2011.02.006

20. Driffield, N., \& Karoglou, M (2019). Brexit and foreign investment in the UK. Journal of the Royal Statistical Society. Series A: Statistics in Society, 182(2), 559-582. https://doi.org/10.1111/ rssa. 12417 
21. Engle, R. F., \& Kroner, K. F. (1995). Multivariate Simultaneous Generalized ARCH. Econometric Theory, 11, 122-150.

22. Engle, R. F., Ito, T., \& Lin, W.-L. (1990). Meteor Showers or Heat Waves? Heteroskedastic IntraDaily Volatility in the Foreign Exchange Market. Econometrica, 58(3), 525-542.

23. Forbes, K. J., \& Rigobon, R. (2002). No contagion, only interdependence: Measuring stock market comovements. The Journal of Finance, 57(5), 2223-2261. https://doi.org/10.1111/00221082.00494

24. Gu, C., \& Hibbert, A. M. (2021). Expectations and financial markets: Lessons from Brexit. The Financial Review, 56(2), 279-299. https://doi.org/10.1111/fire.12248

25. Guedes, E. F., Ferreira, P., Dionísio, A., \& Zebende, G. F. (2019). An econophysics approach to study the effect of BREXIT referendum on European Union stock markets. Physica A: Statistical Mechanics and Its Applications, 523, 11751182. https://doi.org/10.1016/j. physa.2019.04.132

26. He, L. T. (2001). Time variation paths of international transmission of stock volatility - US vs. Hong Kong and South Korea. Global Finance Journal, 12, 79-93. https://doi.org/10.1016/ S1044-0283(01)00022-9

27. Hosoe, N. (2018). Impact of border barriers, returning migrants, and trade diversion in Brexit: Firm exit and loss of variety. Economic Modelling, 69, 193-204. https://doi.org/10.1016/j. econmod.2017.09.018

28. Hung, N. T. (2019). Return and volatility spillover across equity markets between China and Southeast Asian countries. Journal of Economics, Finance and Administrative Science, 24(47), 66-81. https://doi.org/10.1108/ JEFAS-10-2018-0106

29. Hung, N. T. (2020). An analysis of CEE equity market integration and their volatility spillover effects. European Journal of Management and Business Economics, 29(1),
23-40. https://doi.org/10.1108/

EJMBE-01-2019-0007

30. Jebran, K., Chen, S., Ullah, I., \& Mirza, S. S. (2017). Does volatility spillover among stock markets varies from normal to turbulent periods? Evidence from emerging markets of Asia. Journal of Finance and Data Science, 3(1-4), 20-30. https://doi.org/10.1016/j. jfds.2017.06.001

31. Kara, A., Karimov, N., \& Nguyen, A. P. (2021). Brexit referendum and the UK securitization market. Applied Economics Letters, 28(13), 1092-1097. https://doi.org/10.108 $0 / 13504851.2020 .1798340$

32. Kim, S. J. (2005). Information leadership in the advanced AsiaPacific stock markets: Return, volatility and volume information spillovers from the US and Japan. Journal of the Japanese and International Economies, 19(3), 338-365. https://doi.org/10.1016/j. jjie.2004.03.002

33. Lai, K. P. Y., \& Pan, F. (2018). Brexit and shifting geographies of financial centres in Asia. Geoforum, 125(January), 201-202. https://doi.org/10.1016/j.geoforum.2018.02.004

34. Li, H. (2020). Volatility spillovers across European stock markets under the uncertainty of Brexit. Economic Modelling, 84, 1-12. https://doi.org/10.1016/j.econmod.2019.03.001

35. Li, Y., \& Giles, D. E. (2015). Modelling volatility spillover effects between developed stock markets and Asian emerging stock markets. International Journal of Finance and Economics, 20(2), 155-177. https://doi. org/10.1002/ijfe.1506

36. Lien, D., Lee, G., Yang, L., \& Zhang, Y. (2018). Volatility spillovers among the U.S. and Asian stock markets: A comparison between the periods of Asian currency crisis and subprime credit crisis. North American Journal of Economics and Finance, 46(June), 187-201. https://doi.org/10.1016/j.najef.2018.04.006

37. Majdoub, J., \& Mansour, W. (2014). Islamic equity market integration and volatility spillover between emerging and US stock markets. North American Journal of Economics and Finance, 29, 452-470. https://doi.org/10.1016/j. najef.2014.06.011

38. McIver, R. P., \& Kang, S. H. (2020). Financial crises and the dynamics of the spillovers between the U.S. and BRICS stock markets. Research in International Business and Finance, 54(October 2017). https://doi.org/10.1016/j.ribaf.2020.101276

39. Mohammadi, H., \& Tan, Y. (2015). Return and volatility spillovers across equity markets in Mainland China, Hong Kong and the United States. Econometrics, 3(2), 215-232. https://doi.org/10.3390/econometrics3020215

40. Ramiah, V., Pham, H. N. A., \& Moosa, I. (2017). The sectoral effects of Brexit on the British economy: early evidence from the reaction of the stock market. Applied Economics, 49(26), 25082514. https://doi.org/10.1080/0003 6846.2016.1240352

41. Roy, A., \& Mathur, S. K. (2016). Brexit and India-EU Free Trade Agreement. Journal of Economic Integration, 31(4), 740-773.

42. Samitas, A., Polyzos, S., \& Siriopoulos, C. (2018). Brexit and financial stability: An agent-based simulation. Economic Modelling, 69(October 2017), 181-192. https://doi.org/10.1016/j.econmod.2017.09.019

43. Sehgal, S., Gupta, P., \& Deisting, F. (2017). Assessing time-varying stock market integration in Economic and Monetary Union for normal and crisis periods. The European Journal of Finance, 23(11), 1025-1058. https://doi.org/ 10.1080/1351847X.2016.1158727

44. Singh, P., Kumar, B., \& Pandey, A. (2010). Price and volatility spillovers across North American, European and Asian stock markets. International Review of Financial Analysis, 19(1), 5564. https://doi.org/10.1016/j. irfa.2009.11.001

45. Stoupos, N., \& Kiohos, A. (2021). Euro area stock markets integration: Empirical evidence 
after the end of 2010 debt crisis. Finance Research Letters, September, 1544-6123. https://doi. org/10.1016/j.frl.2021.102423

46. Tamakoshi, G., \& Hamori, S. (2014). Co-movements among major European exchange rates: A multivariate timevarying asymmetric approach. International Review of Economics and Finance, 31, 105-113. https:// doi.org/10.1016/j.iref.2014.01.016

47. Teague, P., \& Donaghey, J. (2018). Brexit: EU social policy and the UK employment model. Industrial Relations Journal, 49(5-6), 512-533. https://doi.org/10.1111/irj.12235
48. Tripathi, D. (2021). Evaluating Brexit Implications for India's Relations with the EU and the UK. International Studies, 58(2), 234-247. https://doi. org/10.1177/00208817211011361

49. Vo, X. V., \& Ellis, C. (2018). International Financial Integration: Stock Return Linkage and Volatility Transmission between Vietnam and Other Advanced Countries. Emerging Markets Review, 36, 19-27. https://doi.org/doi.org/10.1016/j. ememar.2018.03.007

50. Yousaf, I., \& Hassan, A. (2019). Linkages between crude oil and emerging Asian stock markets: New evidence from the Chinese stock market crash. Finance Research Letters, 31, 207-217. https://doi. org/10.1016/j.frl.2019.08.023

51. Zhou, X., Zhang, W., \& Zhang, J. (2012). Volatility spillovers between the Chinese and world equity markets. Pacific Basin Finance Journal, 20(2), 247-270. https://doi.org/10.1016/j.pacfin.2011.08.002

52. Zorgati, I., Lakhal, F., \& Zaabi, E. (2019). Financial contagion in the subprime crisis context: A copula approach. North American Journal of Economics and Finance, 47(November 2018), 269-282. https://doi.org/10.1016/j.najef.2018.11.014 